\title{
熱延ランナウトテーブル通板解析*
}

\section{（ROT 通板不安定現象に対する実験的検討）}

\author{
青江 信一郎*1, 小原祐 司 ${ }^{* 2}$, 林 \\ 石野和成*1, 原一堅治*3, 北浜正法*2 \\ Strip Running Analysis on Hot Run-Out-Table \\ (Experimental Approach for ROT Strip Running Unstability) \\ Shin-ichiro AOE*4, Yuji OHARA, Hiromasa HAYASHI, \\ Kazushige ISHINO, Kenji HARA and Masanori KITAHAMA \\ ${ }^{* 4}$ Mechanical Engineering Department, JFE R \& D Corporation, \\ 1-1 Minamiwatarida-cho, Kawasaki-ku, Kawasaki-shi, Kanagawa, 210-0855 Japan
}

\begin{abstract}
In the Hot-Rolling process, when a thin strip runs on the Run-Out-Table (ROT) at high speed in the state of non-tension (a head or a tail of a strip), the defects resulting from the running instability pose a chronic problem. Moreover, for the running unstable phenomenon, the maximum line speed has been restrained, and has also become a prevention factor of productivity. In order to solve and improve this problem, various methods have been proposed from the former, but it has not eradicated completely. In this paper, we propose two types of the experimental method to simulate the ROT running phenomenon in a laboratory. The ROT strip running unstability theorem was proven by using them experimentally. By utilizing them, the improvement cost and term become cheaper and shorter.
\end{abstract}

Key Words: Hot-Rolling Process, Strip, Beam, Run-Out-Table, ROT, Unstable, Buckling, Motion Equation, Similarity, Experimental Device, Simulator

\section{1. 緒 論}

鋼板の熱間圧延工程では，ストリップは仕上げ圧延 において所定の板厚まで圧延加工された後に, 100〜 $150 \mathrm{~m}$ 程度の水冷帯に扔いて所定の温度まで冷却さ れ，コイラーに巻き取られる。ストリップの最先端や 最尾端は, 水冷帯のランアウトテーブル (以下 ROT) を無張力かつ高速で走行する。その速度は，ミルおよ び操業条件により異なるが,一般的に $11 \mathrm{~m} / \mathrm{s}$ 程度に 達する。比較的薄いストリップでは，ROT上を走行 する際に，「頭折れ」(図 1)，「ダブり込み」(図 2)等の 名称で呼ばれる通板不安定性に起因する欠陷が慢性的 な問題となっている.

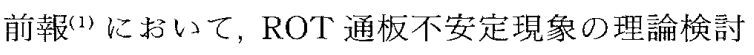
を行い, そのメカニズムの本質を理論的に解明した。 ROT 通板不安定現象は, 遠心力に起因する慣性圧縮 力が軸力方向に作用した座屈問題(ROT 通板不安定 現象と座屈現象の等価原理)であり,一般的には固有

\footnotetext{
* 原稿受付 2008 年 9 月 10 日.

*1 正員, JFE 技研(株) ( $\mathbf{M} 210-0855$ 川崎市川崎区南渡田町 I1).

*2 JFE 技研(株).

*3 JFE スチール(株) (事 210-0868 川崎市川崎区扇島 1-1).

E-mail : $s^{-a o e @ j f e-r d . c o . j p ~}$
}

值問題である，座屈荷重に対応する安定・不安定の臨 界速度 (ROT 通板安定限界速度)を,

$$
P_{C}=\rho A v_{c}^{2}
$$

で求めることができる。ここで， $P_{C}$ は座屈荷重値， $\rho$ はストリップの密度, A はストリップの断面積, $v_{C}$ は 通板安定限界速度である。

また，テーブルロールが等ピッチで配置されている

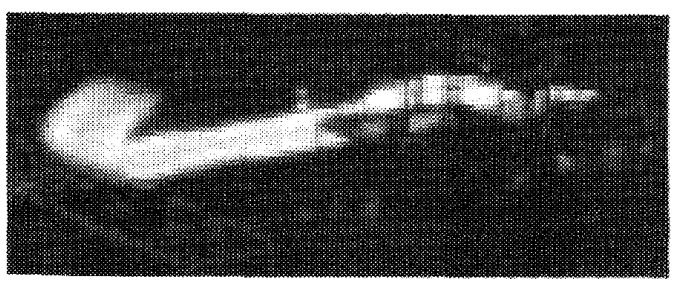

Fig. 1 Folded defect in head

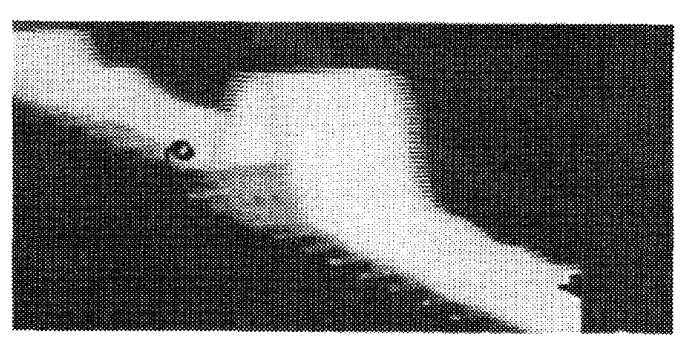

Fig. 2 Folded defect in middle 
場合，ストリップの先端に空力が作用する場合におけ る ROT 通板安定限界速度の理論解を求めた。さら に, テーブルロール摩擦力が作用する場合について考 察した。

実際の熱延ラインで発生するROT 通板現象は，又 トリップの力学特性および周辺設備の外乱等による未 観測情報が多く含まれた現象であるため，実操業のデ 一夕から理論を証明することは困難である。また実際 の生産ラインでは，実験費用が莫大で時間的制約も大 きく，実質的に不可能である，可能な限り理論に基づ いて理想化された実験室レベルで安価なラボ通板試験 を行うことができれば，理論の確証，現象の詳細な観 察が可能となる。また理論では安定・不安定の臨界点 しかわからないが，ラボ通板試験では不安定へ移行し た後のストリップの詳しい挙動も観測することが可能 となる。さらにラボ実験機で得られた知見を実際の熱 延ラインへ適用することも可能となる。

エンジニアリング的な観点に立つと，本研究の目的 は通板安定限界速度を上げることであるから，式（1） から座屈荷重值を上げればよいことがわかる，実際の 熱延ラインの複雑な設備条件下で座屈荷重の理論值を 求めることは困難である。したがって座屈荷重值を実 験的に求めることができれば，ROTを実験的に評価 することが可能となる。さらに実験的に座屈荷重向上 手段を考案することが可能となる.

本論文では，まず実機 ROTの通板現象を実験室で 再現するための実験方法, 実験装置(ランナウトシミ ュレータ)邨びその実験結果について述心゙る。次に $\mathrm{ROT}$ 上の板の座屈荷重を求めるための座屈試験実験 方法，扔よびその実験結果について述べる.

\section{2. ランナウトシミュレータによる}

\section{ROT 通板安定限界理論の実験的検証}

ランナウトシミュレータ(以下ROS) とは，実機

Table 1 Specification of ROS

\begin{tabular}{|l|l|}
\hline Table Roller Diameter & $\phi 40 \mathrm{~mm}$ \\
\hline Table Roller Pitch & $43 \mathrm{~mm}$ \\
\hline Maximum Velocity & $5 \mathrm{~m} / \mathrm{s}$ \\
\hline Roller Material & Aluminum Alloy \\
\hline
\end{tabular}

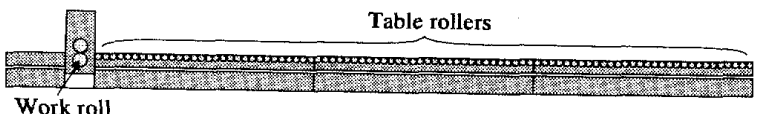

Fig. 3 Run-out simulator
ROTを模擬 (スケールダウン)した通板実験を行うた めの実験装置である，実機と核添同等の通板現象が再 現できるために，直感的な通板現象の把握を可能とす る.

$2 \cdot 1$ 実験装置(ランナウトシミュレータ) 図 3 に ROS の模式図を示す. ROS は実機 ROT の約 1/ 10 スケールであり，実機と同様に上下ワークロールか らシートを送り出し, 複数のテーブルロールを模擬し た搬送ロール群上にシートを通板させる実験装置であ る.表 1 に ROS の仕様を示す.テーブルロール周速 度は最大で $5 \mathrm{~m} / \mathrm{s}(2400 \mathrm{rpm})$ まで上げることが可能 である。全てのテーブルロールは同じ速度で回転す る、テーブルロール群の上側には，通板材の浮き上が り高さ(ループ高さ)を計測するためのレーザ変位計が 所定ピッチ毎に設けてある。ループ高さの計測值を用 いて，安定か不安定かを判明する．また，不安定な場 合には，ループ高さの大きさをもつて不安定の度合い を評価する。

$2 \cdot 2$ ROT 通板現象の相似則 実機と ROS では サイズ，通板材の物性が異なるので，両者の間の整合 性をとるために，ROT 通板現象の相似則を導く必要 がある。

ROT 上を安定に走行するストリップのたわみは微 小であると仮定して，ストリップの運動方程式を定式 化すると式(2)で表される(2)(3).

$$
\begin{aligned}
& \frac{\partial^{2}}{\partial x^{2}} E I \frac{\partial^{2} w}{\partial x^{2}}+\frac{\mathrm{D}}{\mathrm{D} t} \rho A \frac{\mathrm{D} w}{\mathrm{D} t}=F \\
& \frac{\mathrm{D}}{\mathrm{D} t}=\frac{\partial}{\partial t}+v \frac{\partial}{\partial x} \ldots \ldots \ldots \ldots \ldots \ldots \ldots \ldots \ldots \ldots \ldots
\end{aligned}
$$

ここで， $t$ はストリップが ROT上を通板開始してか らの時間， $x$ はストリップ進行方向の位置であり，ワ ークロール位置を零として空間に固定されている， $w$ はストリップの鉛直方向のたわみ， $E$ はストリップの 縦弾性係数, I はストリップの断面二次モーメント, $F$ は鉛直方向の分布荷重, $\mathrm{D} / \mathrm{D} t$ は式 $(3)$ で定義され る物質微分, $v$ は通板速度である。

式（2）の運動方程式に枕いて，ストリップの物性， 形状值はストリップ移動方向に対して一定であり，分 布荷重 $F$ がテーブルロールの摩擦力, ストリップに 作用する空力，自重により構成されているとすると次 式のストリップの運動方程式が成り立つ.

$$
\begin{gathered}
E I \frac{\partial^{4} w}{\partial x^{4}}+\rho A \frac{\mathrm{D}^{2} w}{\mathrm{D} t^{2}}-\frac{\partial}{\partial x} \mu \rho A g(v t-x) \frac{\partial w}{\partial x} \\
-\frac{1}{2} C_{L} \rho_{a} W v^{2} \frac{\partial w}{\partial x}+\rho A g=0 \quad(0 \leq x \leq v t)
\end{gathered}
$$


数, $g$ は重力加速度, $C_{L}$ は揚力係数, $\rho_{a}$ 屾空気密度, $W$ はストリップ幅である。

式 (4)の左辺第二項の物質微分項を定常化し，ス卜 リップに作用する摩擦力, 空力, 重力を微小とすると, ストリップの定常状態の運動方程式は式 (5)で表され 方.

$$
E I \frac{\mathrm{d}^{4} w}{\mathrm{~d} x^{4}}+\rho A v^{2} \frac{\mathrm{d}^{2} w}{\mathrm{~d} x^{2}}=0
$$

式( 5 )に ROT 通板不安定現象と座屈現象の等価原理 (固有值問題) (1) を用いると, 式(1)のROT 通板安定 限界速度が求められる。

式 (4) を無次元化すると, ストリップの運動方程式 は式(6)となる。

$$
\frac{\partial^{4} \omega}{\partial \xi^{4}}+\alpha \frac{\mathrm{D}^{2} \omega}{\mathrm{D} \tau^{2}}-\frac{\alpha}{\beta} \frac{\partial}{\partial \xi} \xi \frac{\partial \omega}{\partial \xi}+\frac{1}{2} C_{L} \gamma \frac{\partial \omega}{\partial \xi}+\delta=0
$$

ここで

$$
\begin{aligned}
& \alpha=\frac{\rho A v^{2} L^{2}}{E I} \\
& \beta=\frac{v^{2}}{\mu g L} \\
& \gamma=\frac{\rho_{a} W v^{2} L^{3}}{E I} \\
& \delta=\frac{\rho A g L^{3}}{E I} \\
& \xi=\frac{v t-x}{L}, \quad \tau=\frac{v}{L} l, \quad \omega=\frac{w}{L}
\end{aligned}
$$

Lは代表長さ(例えばロールピッチ)である。無次元 数 $\alpha, \beta, \gamma, \delta$ は，おのおの(慣性力) /(岡性)，(慣性 力) $/($ 摩擦力), (空力) /(剛性), (重力) /(剛性)の意味 がある.これらの無次元数の全てが，実機 ROTと ROSで同じになれば，両者の通板現象は同等となる (相似則).

\section{$2 \cdot 3$ 実験目的 本実験の目的は，ROT の通板不} 安定現象の指導原理式である式 (1)が成り立つかどう かを実験的に検証すること，また式(1) から求まる等 ピッチで配置されたテーブルロールの場合における ROT 通板安定限界速度の理論式 (12) (4) が成り立つか どうかを実験的に検証することである。

$$
v_{C}=\frac{\pi}{L} \sqrt{\frac{E I}{\rho A}}=\frac{\sqrt{3} \pi h}{6 L} \sqrt{\frac{E}{\rho}}
$$

ここで，Lはテーブルロールピッチ， $h$ はストリップ 板厚である。

$2 \cdot 4$ 実験条件の選定（無次元数 $\alpha$ ) 実験目的か ら，最も重要な無次元数は $\alpha$ である. ROT 通板限界 速度 $v_{C}$ に打ける臨界無次元数 $\alpha_{C}$ は, 式(12)を式(7) へ代入すると求められる.

$$
\alpha_{C}=\pi^{2} \approx 9.8696
$$

通板不安定現象を発現させるためには，式（７）の無
次元数 $\alpha$ が式(13)の臨界無次元数 $\alpha_{C}$ 付近の值になる ように実験条件を設定する必要がある。本実験では， 試験材として一般的なナイロン材を選定した。その理 由としては, $5 \mathrm{~m} / \mathrm{s}$ (表 1 に示す $\mathrm{ROS}$ の最大速度)以内 の通板速度で,ナイロンの物性值(密度, 縦弾性係数) と市販のナイロンシート材の板厚から求まる式 (7)の 無次元数 $\alpha$ が式(13)の条件を満たしやすいことであ る.ナイロン材ということで, 温度変化により縦弾性 係数が変化してしまうために, 公称の物性值に信頼性 がそしい.したがって，所定の温度条件下で共振法を 用いて縦弾性係数を計測した。また, 実験時にナイロ ン材が常に同じ温度となるように，恒温機を用いてナ イロン材の温度管理を行った。

$2 \cdot 5$ 実験条件の選定 (無次元数 $\beta$ ) 次に重要な 無次元数は $\beta$ である. 無次元数 $\beta$ は慣性力と摩擦力 の比であり, 先端からの不安定領域の長さ(ロール本 数)を意味している(1). 無次元数 $\beta$ が小さすぎると, 不安定領域が短くなりすぎて，場合によっては通板不 安定性がROSによる実験では現れない, 観測しにく くなる。

ROT 通板安定限界速度 $v_{C}$ に扔ける臨界無次元数 $\beta_{C}$ は式 (8), 式(12)から次式であらわされる.

$$
\beta_{C}=\frac{v_{C}^{2}}{\mu g L}=\frac{\pi^{2} E I}{\mu \rho A g L^{3}}=\frac{\pi^{2} E h^{2}}{12 \mu \rho g L^{3}}
$$

式(14) から板厚 $h$ 変更卞れば，臨界無次元数 $\beta_{c}$ を調整することが可能である。しかしながら, 臨界無 次元数 $\beta_{C}$ を大きく寸るために板厚を大きく寸ると， 式(12)から ROT 通板安定限界速度も大きくなる。 ROT 通板安定限界速度は, ROS の通板速度仕様範囲 以内にする必要がある。

摩擦係数 $\mu$ に関しては, 所定長さのアルミ板の裏に 通板材を貼り付けた試験材を作成し，試験材をテーブ ルロール上に招き，テーブルロールを回転させたとき に作用する摩擦力を計測し，その摩摖力と試験材の自 重の比から実験的に求めた。

$2 \cdot 6$ 実験条件の選定 (無次元数 $\gamma, \delta$ ) パラメ 一夕 $\gamma$ は板剛性に対する空力の影響度合いを示すパ ラメータであり，図１に示す頭折れのような最先端の 不安定現象に関係する。 ROT 通板安定限界速度 $v_{C}$ に招都界無次元数 $\gamma_{C}$ は式 (9), 式(12) から次式 であらわされる。

$$
\gamma_{c}=\frac{\rho_{a} W v_{c}^{2} L^{3}}{E I}=\frac{\pi^{2} \rho_{a} L}{\rho h}
$$

本実験の目的において, 空力の影響を考える必要は ない.しかしながら臨界無次元数 $\gamma_{c}$ が大きいと頭折 れが多発し，その影響で本来の通板試験を行うことが できないので, 通板材の最先端部位のみを場合によっ 
ては補強する必要がある。補強の方法としては，粘着 テープを貼り付けることで板厚を厚くする方法が最も シンプルであるが，最先端部位の自重も重くなるため 最先端部位の摩擦力が大きくなり，その影響で ROT 通板安定限界速度が高くなる副作用がある。したがっ てあまり最先端部位の自重を重くしすぎないように注 意するべきである。

無次元数 $\delta$ は板剛性に対する重力の影響度合い炎 示すパラメータである。本実験の目的において，重力 の影響を考える必要はないので無視する。

$2 \cdot 7$ 実験条件 表 2 に最終的に選定した実験条 件を示す．本実験では，板愿 $0.21 \mathrm{~mm}$ (Case 1) と板厚 $0.31 \mathrm{~mm}$ (Case 2)の2 水準の通板材を選定した。式 (14), 式(15), 式(10) 汃ら得られる無次元数 $\beta_{C}, \gamma_{C}, \delta$ および前報(1)にて示した頭折れが発生するROT通板 安定限界速度 $v_{C}^{\text {Head }}$ と式(12) から得られる ROT 通板 安定限界速度 $v_{c}$ も表 2 に示す。 また比較・参考 夕として実機 ROTに执実際に操業されているス トリップの仕様を表 2 に示す. 本論文では $v_{C}^{\text {Head }}$ めるために, 揚力係数 $C_{L}$ をクッ夕・ジューコフスキ -D定理 ${ }^{(5)}$ 加ら求められる平板に対する揚力係数と した. 揚力係数は式 (16) となる.

$$
C_{L}=2 \pi
$$

ただし，今回のような半無限長平板問題に対して有 限言平板の揚力係数が妥当かどうかについては疑問が 残るところである. 事実, 経験的, 数值解析的にはこ の揚力係数值より小さい值とするほうが，現実の現象 に近くなることはわかっているが，この值を本論文で は採用する。

Case 1 と Case 2 を比較すると, 板厚が大きいため

Table 2 Experimental conditions

\begin{tabular}{|l|l|l|l|}
\hline & Case 1 (ROS) & Case 2 (ROS) & \multicolumn{1}{c|}{ ROT } \\
\hline$\rho$ & $1261 \mathrm{~kg} / \mathrm{m}^{3}$ & $1261 \mathrm{~kg} / \mathrm{m}^{3}$ & $7800 \mathrm{~kg} / \mathrm{m}^{3}$ \\
\hline$E$ & $3.3 \mathrm{E}+8 \mathrm{~Pa}$ & $3.3 \mathrm{E}+8 \mathrm{~Pa}$ & $1.2 \mathrm{E}+11 \mathrm{~Pa}$ \\
\hline$h$ & $0.21 \mathrm{~mm}$ & $0.31 \mathrm{~mm}$ & $1.2 \mathrm{~mm}$ \\
\hline$W$ & $70 \mathrm{~mm}$ & $70 \mathrm{~mm}$ & $1000 \mathrm{~mm}$ \\
\hline$\mu$ & 0.47 & 0.47 & 0.2 \\
\hline$\alpha_{c}$ & 9.8686 & 9.8686 & 9.8686 \\
\hline$\beta_{c}$ & 25.92 & 56.48 & 125.48 \\
\hline$\gamma_{c}$ & 1.92 & 1.30 & 0.53 \\
\hline$\delta$ & 0.81 & 0.37 & 0.39 \\
\hline$v_{c}^{\text {Head }}$ & $1.59 \mathrm{~m} / \mathrm{s}$ & $2.47 \mathrm{~m} / \mathrm{s}$ & $9.12 \mathrm{~m} / \mathrm{s}$ \\
\hline$v_{c}$ & $2.27 \mathrm{~m} / \mathrm{s}$ & $3.34 \mathrm{~m} / \mathrm{s}$ & $10.16 \mathrm{~m} / \mathrm{s}$ \\
\hline
\end{tabular}

Case 2 の ROT通板安定限界速度の理論值は当然 Case 1 より大きくなる. Case 2 で注通板速度を大き くする必要があり, 速度が大きいために現象の計測, 観測が困難となる。

Case 2 の臨界無次元数 $\beta_{C}$ は Case 1 よりも大きく, 不安定現象長さが長くなり，その意味では，現象の計 測, 観測がしやすくなる.

Case 1 の臨界無次元数 $\gamma_{c}$ は Case 2 よりも大きく, 頭折れが発生しやすいことが予想される，頭折れが発 生寸る ROT 通板安定限界速度 $v_{C}^{\text {Head }}$ と ROT 通板安 定限界速度 $v_{C}$ の乘離が実機 ROTに比べて ROSで は大きいために, ROT 通板安定限界速度 $v_{C}$ に至るま でに巨大な頭折れが発生し, 実機 ROT で発生するよ うなループ発生現象を観測できなかった。. $v_{C}^{\text {Head }}$ げるために, 最先端部位のみを補強した。

Case 1 と Case 2 ともに一長一短をもつているが, $\operatorname{ROS}$ の最大速度仕様 $5 \mathrm{~m} / \mathrm{s}$ を考慮すると, Case 1 が より通板材としては適している.もし Case 1 よりも 板厚を小さくすれば，通板速度は低くできるものの， 不安定現象長さが短くなりすぎるため ROT 通板安定 限界速度以上の領域においても不安定現象の発生がみ られなくなる。

$2 \cdot 8$ 実験結果図 4 にC Case 1 およびCase 2 の 実験結果を示す，横軸は通板速度，縦軸はレーザ变位 計で計測された最大ループ高さである、菱形のプロッ ト(凡例で t 0.21) は Case 1 の実験結果, 正方形のプ ロット(凡例で t 0.31) は Case 2 の実験結果を示して いる。実験は同一実験条件下で複数回実施し，その平 均值をプロットしている，当然ではあるが, 不安定領 域では個々のサンプル間での最大ループ高さの再現 性，相関性はなく，統計処理により傾向が得られる.

図 4 から, 実験により得られたループの発生, 非発 生の境目となる通板速度と式(12)の ROT 通板安定限 界速度の理論值はよく一致していることがわかる。

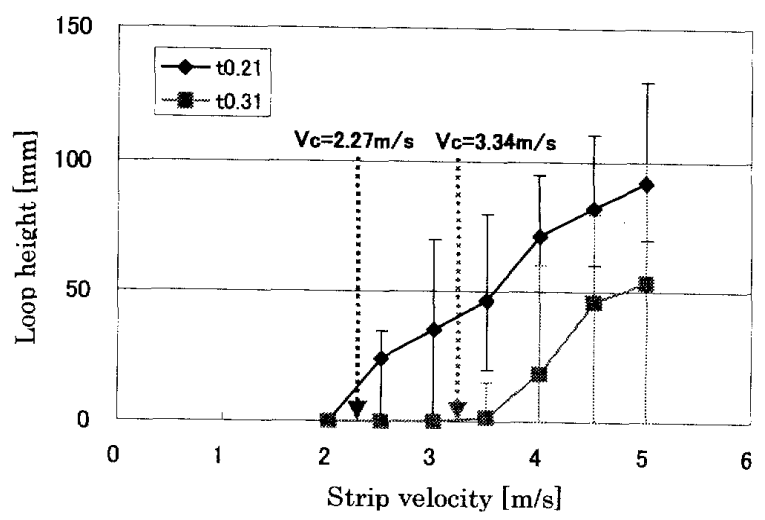

Fig. 4 Experimental results 
通板速度が ROT 通板安定限界速度以上の領域で は，通板速度が大きい活どループ高さも高くなる。 個々のサンプルでみれば, 通板速度が ROT 通板安定 限界速度以上であってもループが発生しない場合もあ る。一方で, 通板速度が ROT 通板安定限界速度以下 の場合には，ループは発生しない。

以上から，ROT 通板安定限界理論は正しいことが 確証された。 ROSで現れる通板不安定現象は実機の ROT と同じ現象であるので, ROSで何らかの通板を 安定化する対策が実現できれば，それを実機のROT へ転用することが可能となり，より定量的な対策の提 案, 開発期間の短縮, 開発コストの低減が可能となる。 ROT 通板不安定現象を他の力学現象の類似で考え てみると, 無次元数 $\alpha$ は, 流体力学に扔けるレイノル ズ数に対応するような無次元数である。すなわち，無 次元数 $\alpha$ が臨界值 $\alpha_{C}$ 以下では, 層流のような安定し た状態である。パラメータ $\alpha$ が臨界值 $\alpha_{C}$ を超えると， ループ高さを予測することが困難な乱流の上うな不安 定な状態になる。

\section{3. ストリップ座屈試験装置}

ROS を用いれば実機を模擬した条件下で実験的に ROT 通板安定限界速度を求めることが可能となる. 別の ROT 通板安定限界速度を求める実験方法とし て，式（1）の等価原理式を用いて，ROT上のストリ ップの座屈荷重から ROT 通板安定限界速度を求める ことも可能である.

$3 \cdot 1$ 実験装置と実験手順＼cjkstart図 5 にストリップ座 屈試験装置の模式図を示す。本装置は，テーブルロー ルを模擬した回転しないパイプ，パイプ群上に置かれ

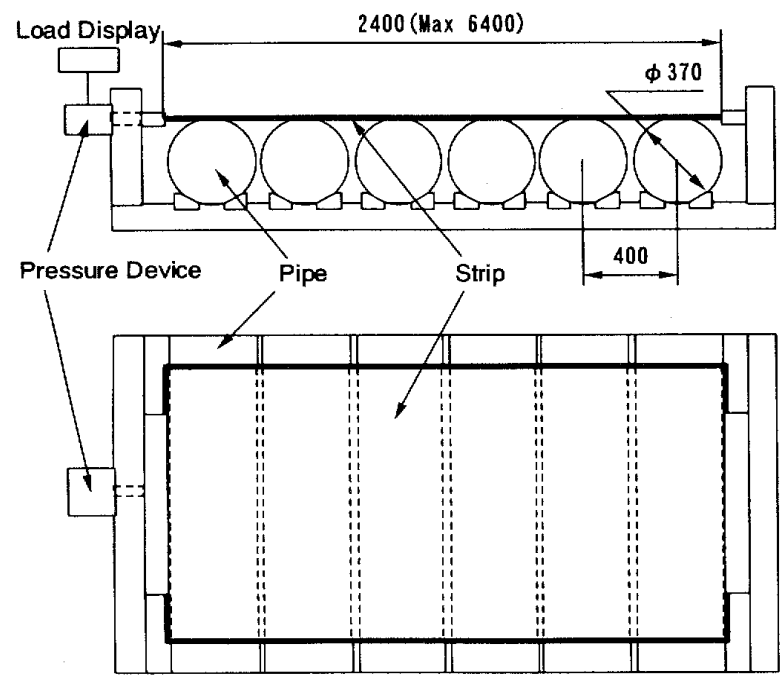

Fig. 5 Strip buckling experimental device
た試験材であるストリップストリップに压縮荷重を 作用させるための手動レバーを備えた油庄式の加圧装 置, 加庄装置内部に設置された死縮荷重を計測用口ー ドセルの荷重表示装置により基本的に構成される。 トリップ座屈試験装置は可動部分はほとんどなく装置 構成がシンプルであるため，実機 ROT 相当のスケー ルのものが安価で製作可能である。

実験手順としては，実験員が手動レバーにより加圧 装置を手動で作動させ, 徐々にストリップに作用する 圧縮荷重を上昇させていく。この間，圧縮荷重值は荷 重表示装置に常に表示されている。圷縮荷重を上昇さ せていくと図 6 のように座屈にいたるが, 座屈の瞬間 に荷重表示装置に表示された荷重值が突然下がるので 実験員がその下がる直前の值 (極大值) を記録する。そ の值を座屈荷重值とする，加庄装置の油圧を抜けば厌 縮荷重が零となり，可逆的にストリップはまた元の状 態に扊る。このような作業を繰り返すうちに，座屈荷 重值近傍の挙動がストリップのたわみ形状等の視覚的 情報から感覚的にわかりはじめると，実験員はその付 近では圧縮荷重を小刻みに上げるなどすることで座屈 荷重值の計測精度が上がってくる.

$3 \cdot 2$ 座屈荷重の換算式 ROT上を走行するス トリップは高温の鋼板であり, 室温の龬板よりも表 2 にしめすように縦弾性係数が低くなる。またストリッ プ座屈試験で用いるストリップ形状，装置寸法は，実

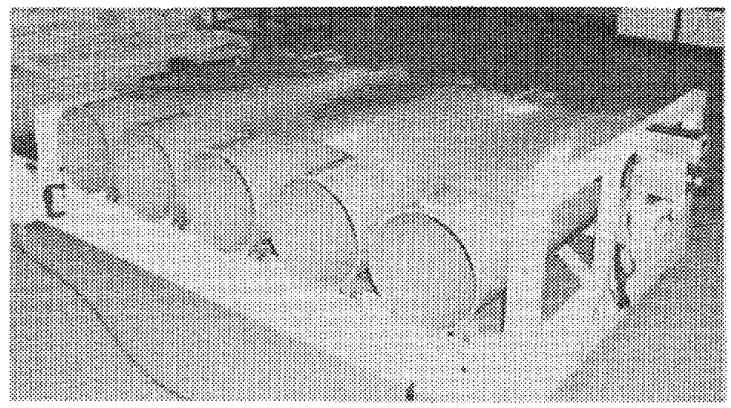

Fig. 6 Buckling mode of strip

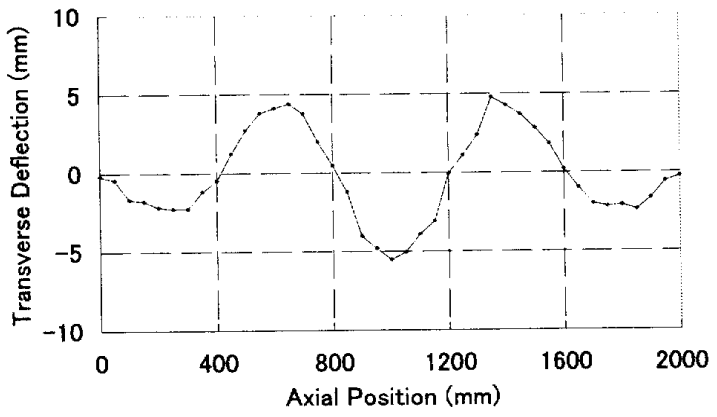

Fig. 7 Transverse deflection of strip 
機 ROT のストリップと若干異なる，ストリップ座屈 試験装置でえられた座屈荷重值を高温のストリップの 座屈荷重へ換算する必要がある。室温鋼板の座屈荷重 を高温鋼板の座屈荷重への換算式は,

$$
P_{C 1}=\frac{E_{1} I_{1} L_{0}^{2}}{E_{0} I_{0} L_{1}^{2}} P_{C 0}
$$

ここで, $P_{C 1}, E_{1}, I_{1}, L_{1}$ は高温鎙板の座屈荷重, 縦弾 性係数, 断面 2 次モーメント, テーブルロール代表ピ ッチであり， $P_{C 0}, E_{0}, I_{0}, L_{0}$ は室温鋼板の座屈荷重, 縦弾性係数, 断面 2 次モーメント, テーブルロール代 表ピッチである.

$3 \cdot 3$ 実験条件と実験結果実験に使用したス卜 リップは板厚 $0.9 \mathrm{~mm}$, 板幅 $1.219 \mathrm{~m}$, 板長 $2.4 \mathrm{~m}$ の 鋼板であり，縦弾性係数は $2.1 \mathrm{E}+11 \mathrm{~Pa}$ である。実

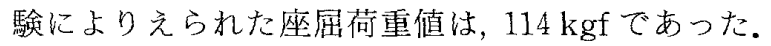
図 7 にストリップたわみ形状計測值のグラフを示す. テーブルロールピッチを半周期とした正弦状の座屈モ ードがあらわれていることがわかる。

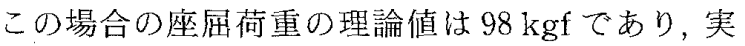
験值は理論值より若干大きめとなるがよく一致してい る.この差異の原因としては, 実験で用いた鋼板が $2.4 \mathrm{~m}$ と短めであるため，ス卜リップ両端の境界条件 の影響が若干現れてしまったものと考えられる。

テーブルロール形状は実機 ROT とストリップ座屈 試験装置で同じとし，式(17) を用いて表 2 の実操業ス トリップ材の座屈荷重 $P_{C 1}$ を計算すると, 座屈荷重值 $P_{C 1}$ は $127 \mathrm{kgf}$ となる。

式 (1)とこの座屈荷重值を用いると, 高温鋼板の ROT 通板安定限界速度は $11.5 \mathrm{~m} / \mathrm{s}$ と算出される。 この值は実操業における経験值とほぼ近い值である。 座屈現象は最も座屈荷重值が低い座屈モードへ座屈 するということが構造力学の定石であり，この考えを 踏襲すると, 最も座屈荷重が低い座屈モードであるス トリップ両端を固定端とした一つの山形状しか現れな いのではという懸念もあった。実験結果は予想どおり の座屈形状が発生しており, ROT 通板不安定現象の 本質は座屈現象であるということが理論の上だけでな く実験的にも証明された。

\section{4. 結言}

本論文では，熱間圧延工程において，比較的薄い久 トリップが無張力状態 (先端, 尾端)で ROT 上を高速 に走行する際に，「頭折れ」,「ダブり込み」等の名称で 呼ばれる通板不安定性について, 実験的な考察を行い, 次に示持成果を得た。

（1）実機ROT をスケールダウンしたROSによ
る通板試験方法を提案した。

（2）ROSと実機 ROTとの間の整合性をとるた めの相似則, 実験パラメータの設定方法を考案した.

(3) ROSの実験でえられた通板安定限界速度は, ROT 通板安定限界速度の理論值とよく一致すること が確認でき，ROT 通板安定限界理論が証明された。

（4）ストリップ座屈試験装置を用いて, ROT 通 板安定限界速度を求める方法を提案した。ストリップ 座屈試験装置は可動部分がほとんど存在しないため に, 装置コストが安価であり，設置も単純であるので， 実験室レベルで実機と同じスケールを模擬することが 可能となる。

（5）ストリップ座屈試験装置よりえられた座屈荷 重值加換算された ROT 通板安定限界速度は経験的 な值，および理論值とほぼ一致する結果がえられた。 このことから ROT 通板不安定現象の本質は座屈現象 であることが証明できた。

ROSを用いることで，通板安定化対策を実験室レ ベルで開発することが可能となり，開発コストの低減， 開発期間の短縮化が見込まれる。また，ストリップ座 屈試験装置にて考案した通板安定化手段(座屈荷重向 上手段) は，そのまま実機へ転用できるため，開発コス トの低減，開発期間の短縮化が見込まれる。

ROS およびストリップ座屈試験装置において，実

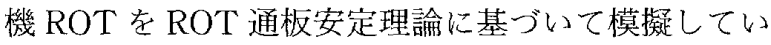
るが，おの扔のにはやはり欠点がある。 ROS はスケ 一ルダウンされた実験装置であるので, 通板安定化手 段をある程度の定量化することには寄与するが作り込 み，実機特性に合わせてカスタマイズする過程に扔い ては若干力不足となる。ストリップ座屈試験装置は通 板が安定している状態を模擬しているので，通板が不 安定な状態については何も回答がえられない。それら を解決するためには，数值シミュレーションの手段が 有效となってくる.

\section{文献}

(1) Aoe, S., Hayashi, H., Ishino, K., Kobayashi, M., Ohara, Y. and Kitahama, S., Transactions of the Japan Society of Mechanical Engineers, Series C, Vol.72, No.721 (2006), pp. 2921-2925.

(2) Mote, C. D., Jr., Journal of The Franklin Institute, Vol. 279, No. 6 (1965), pp. 430-445.

(3) Galip Ulsoy, A., Joumal of Vibration, Acoustic, Stress, Vol. 108 (1986), pp. 207-212, Reliability in Design.

(4) Nakamura, Y. et al., METHOD AND DEVICE FOR CONVEYING STRIP IN HOT ROLLING, Japanese Patent Disclosure, 2000-225410, A (2000).

(5) Murata, S. et al., Fluid Mechanics, (1979), pp. 52-53, Morikita Publishing. 